\title{
POVERTY AND TRANSPORT IN THE GLOBAL SOUTH: AN OVERVIEW
}

\author{
Rodolfo Benevenuto, PhD Research student at Trinity College Dublin \\ Brian Caulfield, Associate Professor at Trinity College Dublin
}

\begin{abstract}
The primary objective of the United Nations Development Programme to 2030 is to lift more than 736 million people out of extreme poverty (UN, 2019). In this sense, this paper addresses the potential contributions of transport policies to poverty reduction in the Global South. Several studies addressing this topic are qualitatively assessed through an extended version of Church et al's (2000) framework of transport-related exclusion. Insights on topics that pervade the interactions between transport and poverty are discussed to shed light on how transport policies can effectively tackle the intergenerational poverty transfer. Finally, this work concludes by connecting such insights and gaps of literature to propose a convergence of the reviewed studies emphasising the importance and urgency of a new standard of transport policies strongly committed to eradicating poverty.
\end{abstract}

Keywords: Poverty reduction; Transport planning; Global South.

\section{Highlights:}

- A new category is proposed to Church et al's (2000) framework;

- Assessment of 40 studies on 8 categories of transport-related exclusion;

- Insights on how transport development could better tackle poverty in Global South

- Connections between transport and the intergenerational poverty transfer;

Please cite as: Benevenuto, R., Caulfield, B, Poverty and transport in the Global South: An Overview, Transport Policy, 79, 2019, p115 - 124

\section{Introduction}

The most widely used index to measure poverty is based only on individual income. According to the World Bank (2017), the international poverty line defines that a person who lives with less than 1.90 USD a day in 2015 purchasing parity power (PPP) is considered as extremely poor. Based on this poverty indicator, the primary objective of the United Nations Development Programme (UNDP) to 2030 is to lift 736 million people out of extreme poverty (UN, 2019). However, evidence has shown that poverty is neither only related nor even perceived as just lack of income (Narayan et al, 2000; Alkire and Santos, 2014; UN, 1995).

One of the largest and most comprehensives surveys about poverty published to date is The Voices of the Poor (Narayan et al, 2000), which summarised 40,000 experiences of poor people from 50 different countries around the world. The findings of this report assert that poverty is perceived as consisting of many interlocking dimensions, in which lack of access to basic infrastructure, rural roads, 
transportation are frequently pointed out as remarkable factors (Narayan et al, 2000). In that sense, new models, as the one proposed by Alkire-Foster (2011), have suggested a non-monetary approach to measure poverty. These models consist of multidimensional analysis at a household level composed of a variety of indicators mostly related to health, education, employment, living standards, and empowerment for example (Alkire-Foster 2011). When considering the multidimensional concept, it is estimated that some 1.3 billion people are still living in poverty (UN, 2019).

Indeed, not all cases of low scores on such indicators are necessarily due to lack of mobility or transport disadvantage. Hence, it is essential in the realm of transport planning and policy to identify, track and map where exactly poverty is mainly linked to transport issues in order to provide more effective strategies that may accelerate the extreme poverty eradication process. This transportrelated exclusion is also often mentioned as 'transport poverty' (Lucas, 2012; Lucas et al 2016), which is caused by direct and indirect interactions of transport disadvantage and social disadvantage.

The studies dedicated to evaluating the connections between poverty and mobility have been initially developed during the late 1960s (Ornati et al, 1969). In the following decades, this theme has been also researched by several other authors from different institutions (Wachs and Kumagai, 1973; Hanson and Hanson, 1980; Armstrong-Wrigh, 1986; Gannon and Liu, 1997; Hammer et al, 2000; De Luca, 2007; Titheridge et al, 2014).

Nevertheless, the extent of studies on the referred subject is not comprehensive enough in geographical terms and has not achieved most of the regions where poverty is widely spread (Porter, 2014), especially in rural areas (IFAD, 2011). Additionally, many of the existing methodologies applied to wealthier and more urbanised countries are not replicable to emerging-market and low-income countries due to the disparity of data availability and level of aggregation of data (Dimitriou, 2013). Rynning et al (2018) also recognises that, despite some parallels that can be drawn, there are fundamental differences in the premises, requirements, and constraints of mobility and accessibility of developing post-colonial cities and those from the Global North. Furthermore, Lucas et al (2016) highlight that there is a need for a specific transport poverty evidence-base tailored to the Global South given the more extreme intensity and extent of the problem within the developing world. To the best knowledge of the authors, no other literature overview addressing the transport-poverty nexus in the entire Global South has been published in an academic journal to date.

Under these circumstances, this study aims to present an overview that highlights some underexposed insights about the central role that transport policies can play in the poverty reduction process of the Global South. This paper, therefore, contributes to the literature by (i) extending and adapting Church et al's (2000) framework of transport-related exclusion to the particularities of the Global South (ii) summarising and categorising relevant findings and methodologies applied to date in this geographical context; and (iii) pointing out important insights and gaps of research that requires attention to shed light on the essential role of transport policy for reducing poverty. Finally, this work 
concludes by connecting such insights and gaps to propose a convergence of the reviewed studies emphasising the importance and urgency of a new standard of transport policies strongly committed to eradicating poverty.

\section{A conceptual framework for poverty and transport}

Few relationships in the dynamics of expansion and transformation of the urban space are as evident as the one established between land use and transport development (Nigriello, 1992). Early reflections under the Marxist framing have pointed out that the transport network is intertwined in the urban fabric with other layers to compose the 'social space' (Lefebvre, 1974). Likewise, Harvey (1980) also recognises the mechanism how transport and spatial patterns can play on the urban development, creating a socially unjust city, where the worse-off are pushed to live in crowded and very small places with poor access to opportunities. Hansen (1959) also argues that accessibility shapes land use, linking, therefore, social outcomes such as urban poverty to urban and transport planning.

However, recent authors have suggested that the relationship between transport and poverty is still marginal in the traditional approaches of mainstream transport planning, which have inevitably entailed in the perpetuation of socio-economic, environmental and spatial inequalities in cities (Levy and Davila, 2017, Levy, 2013; Lucas, 2012; Vasconcellos, 2001).

Particularly in the academic literature, several frameworks have been published to date describing how transport relates to the social exclusion (see Currie and Delbosc, 2010; Cass et al 2005; Wixey et al., 2005; Hine and Mitchell, 2017; Church et al, 2000). Despite being two different social constructs, poverty and social exclusion have still an undeniable intersection, since people who are socially excluded are as a rule also poor, particularly if poverty is defined in a multidimensional way (Khan et al, 2015).

Generally, the arguments to make a firm distinction of such concepts are based on the idea of a unidimensional concept of poverty (i.e. income-poverty) (see Kenyon et al 2002). However, a substantial body of literature has been dedicated to addressing the multidimensional concept of poverty over the past few decades. Such update in the understanding of poverty is clearly seen since the definition of absolute poverty established by the United Nations at the Copenhagen summit in 1995 ,

"[Absolute poverty is] a condition characterised by severe deprivation of basic human needs, including food, safe drinking water, sanitation facilities, health, shelter, education and information. It depends not only on income but also on access to services" (UN, 1995).

This study builds on Church et al's (2000) categories, not only because it is one of the most recognised frameworks on this topic, but also because it is compatible to the concept of 
multidimensional poverty previously described. Each one of the seven transport-related exclusion dimensions proposed by Church et al (2000) is revisited and illustrated by real examples from the Global South in the following topics. As already pointed out by Hernandez and Titheridge (2016), while some of Church et al's (2000) dimensions can overlap, especially in the context of severe deprivation, they provide initial criteria to distill the mechanisms by which transport policies can effectively contribute to breaking cycles of poverty. Alongside the seven dimensions established by Church, the present study proposes the introduction of an eighth dimension that refers to the transport-related exclusion based on one's social position (i.e. gender, race, ethnicity, religion, etc). Further clarifications and examples of this new dimension are provided below.

I. Physical exclusion: This refers to physical barriers at a micro-level that affect the mobility of certain groups of people (e.g. people with visual, hearing or mobility disabilities). Kabia et al (2018) report that women with mobility and visual disabilities in Kenya were either denied transport or charged a higher fee because their boarding process requires greater assistance, and this was viewed to be more time-consuming for the transport providers.

II. Geographical exclusion: Authors have shown that the location where one lives has a great influence on his/her accessibility to transport services. Vasconcellos (2005) explains that although people in extreme poverty of São Paulo's (Brazil) urban fringe spend proportionally a greater share of their income on transport than any other social strata, they have less than half of the mobility level than the richest in average, and have almost none contribution to transport externalities.

III. Exclusion from facilities: Beyond the exclusion from the transport network there is the exclusion from key facilities such as hospitals, schools, shops is often argued to be one of the reasons behind the poverty trap. Farrow et al (2005) for example confirm that greater access to markets is highly associated with lower levels of food poverty in Ecuador.

IV. Economic exclusion: Affordability is frequently pointed out as the biggest barrier to access the transport system for low-income people (Vasconcellos, 2005; Lau, 2010; Lucas, 2011; and Adeel, 2016). Guzman et al (2017b) state that if appropriate subsidies are applied on bus and Transmilenio (Bogotá's BRT) fares, the job-accessibility for low-income workers may increase up to $28.3 \%$.

V. Time-based exclusion: This feature explains how lengthy journey times might exclude may exclude ever more vulnerable groups that are time poor mostly due to other timeconsuming responsibilities (e.g. household and child-care duties). Motte-Baumvol and Nassi (2012) report that women from Rio de Janeiro (Brazil) have lower mobility than men due to a heavier burden on women in the family care, even having the same transport opportunities for both genders. 
VI. Fear-based exclusion: Exclusion can be even more exacerbated due to unsafe public space and services. Anand and Tiwari (2006) maintain that due to the absence of footpaths, poor location of bus shelters, high steps of public buses, and risk of sexual harassment while traveling, women's mobility is very reduced in Delhi (India), which is inextricably linked to poverty.

VII. Space exclusion: Restrictions on access for certain groups of people in particular areas or routes (e.g gated communities, or areas under control of militias). Hernandez and Titheridge (2016) explain that local criminal groups are responsible for physically restricting neighbourhood's mobility by even imposing tolls to the right to circulate in certain areas of Soacha (Colombia). Despite these restrictions being sometimes enforced by non-official authorities, it is still a different case than the fear-based exclusion since it prevents the accessibility of people not only by the feeling of insecurity but literally by spatial selective barriers just as in a gated community.

VIII. Social position-based exclusion: This transport-related exclusion dimension, that is proposed, refers to the prevention from moving in public space due to censure, social control or any other restriction based on one's social position (i.e. gender, race, ethnicity, cast, religion, etc). Remarkable and not so old examples of this go from the 'white-only' carriages until the early '90s in South Africa (Seekings, 2008) to the ban on women's driving (Rajkhan, 2014) until the year 2018 in Saudi Arabia. The inevitable legacy of historic cases like these is still currently perceived in form of discrimination of public and private transport users (Cano, 2010; Seiler, 2007). For instance, Adeel et al (2016) reports that women face additional mobility constraints in Pakistan such as lack of walking, permission from home and need for veiling and escort during travel due to social and cultural patterns. Similarly, Özkazanç and Sönmez (2017) report that in Turkey women have been excluded from transportation, which leads to social relationship disruptions because they face pressure from society to be home before dark, as well as harassment in traffic simply due to the very fact that they are women. The outcomes of such gendered segregation in mobility have been also revealed by several other authors from Ghana, Malawi, South Africa, Colombia, Lesotho, India, Kenya and China in statistical, spatial and qualitative findings (Kabia et al, 2018; Rodriguez et al, 2016; Hernandez and Titheridge, 2016; Lau, 2013; Porter et al, 2012; Vajjhala and Walker, 2010; Anand and Tiwari, 2006). Evidence of transport-related exclusion based on the social position has been also raised by the survey and interviews performed by Lau (2013) in China. The author reports that one of the limiting factors on low-income migrant workers travel patterns is that they cannot receive social welfare (and thus cannot afford longer and more expensive trips) due to the very fact that they are not recognised as local citizens. Another facet of such dimension is reported by Ramos \& Musumeci (2005) revealing that in Brazil the proportion of black and brown people among those who declared to have been stopped by the police while walking or using public transport was higher than the corresponding share of such racial groups in the population. Thus, 
considering the lack of coverage of such aspects in the original seven categories proposed by Church et al (2000), it is argued that the Socio Position-based dimension should be also recognised into future studies using such a framework in order to ensure clear evaluations of the intersectionality of these social features and its outcomes upon the travel patterns of the most vulnerable population.

The methodology utilised for the selection of the 40 papers reviewed in this study, as well as a summary table showing the classification and a brief description of the main insight of each paper on the transport-poverty nexus, both are included in the Research Data file provided alongside with this study.

When analysing the frequency distribution of the eight dimensions that are covered by these studies, overall the authors tend to converge towards the Geographic, From facilities, and Economic dimensions of transport-related exclusions. Figure 1 summarises such distribution of dimensions that have been addressed in the 40 the reviewed papers.

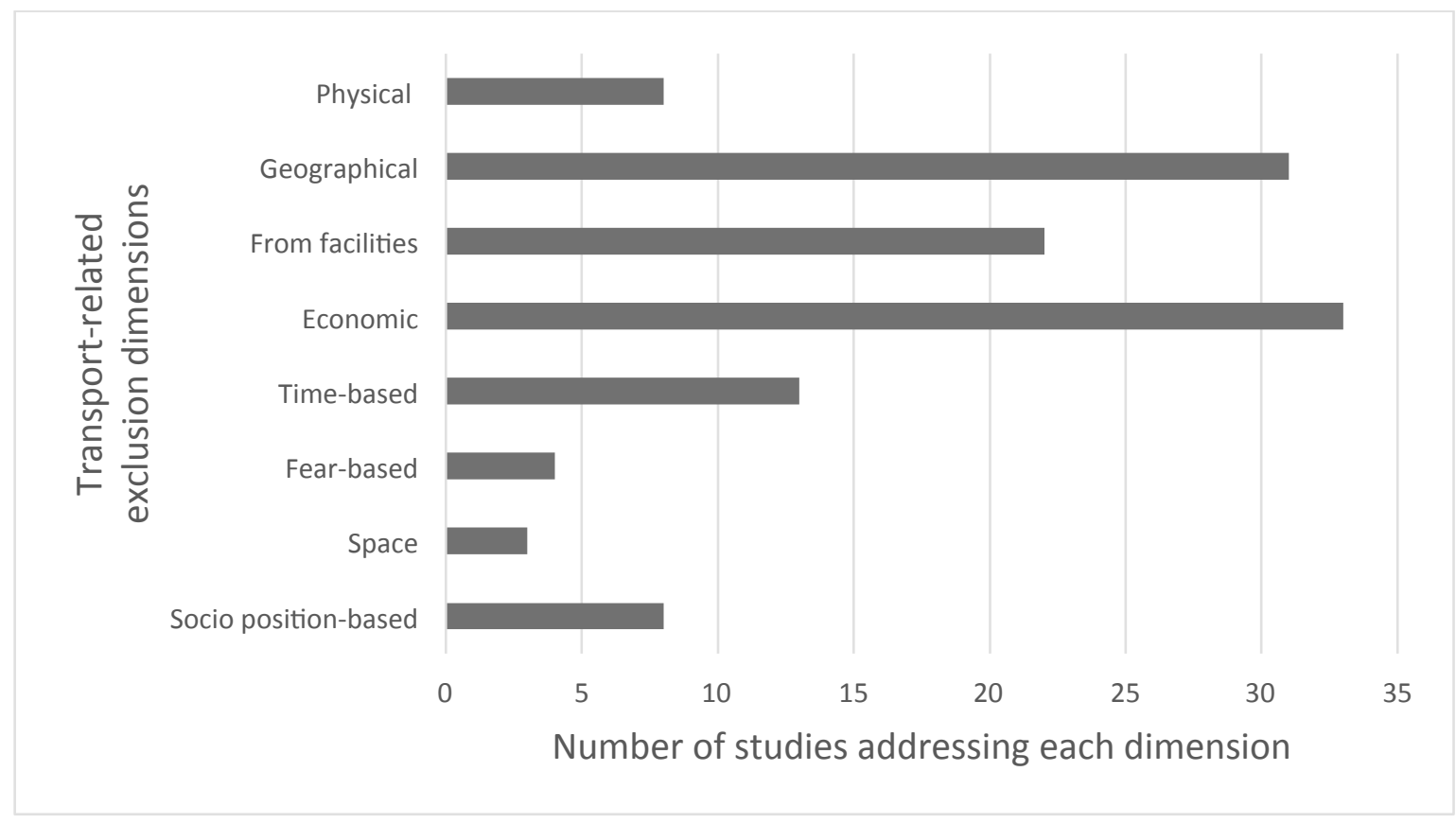

Figure 1: Frequency distribution of the transport-related exclusions dimensions addressed in the reviewed papers

In terms of spatial distribution, among the 22 Countries depicted in the reviewed papers, China and Colombia stand out as the two most targeted Countries for this kind of analysis, accounting for 8 and 5 studies each respectively. Figure 2 represents the spatial distribution of them. Even though the majority of the reviewed studies (48\%) have addressed urban areas alone, it is important to remark that $20 \%$ of them have presented analysis covering both rural and urban contexts and $32 \%$ of them have addressed the transport-poverty nexus in rural contexts alone. Moreover, just one study has been found covering this topic in rural areas of a Latin American country (Farrow et al, 2005). 

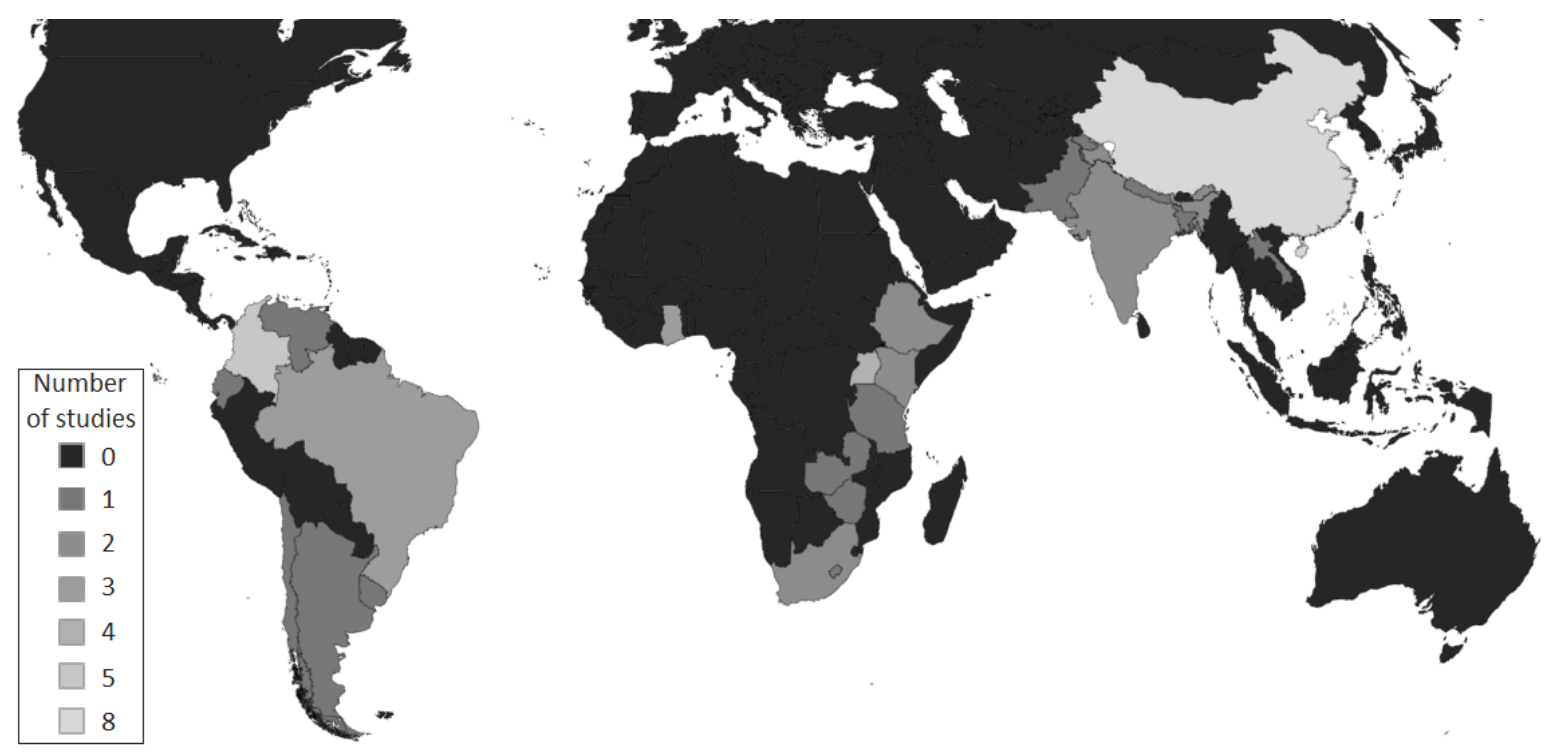

Figure 2: Spatial distribution of publications addressing Transport and Poverty in the Global South

\section{Empirical insights}

The reviewed papers converge around the extent and severity of the multi-dimensional poverty and social inequalities present in the Global South that arises from transport-related exclusion in its various forms. However, the traditional links and mechanisms illustrating such relationship have been consistently reported in similar reviews of literature from urban Latin America (Blanco et al, 2018), rural Sub-Saharan Africa (Porter, 2014), as well as from more general contexts (Booth, 2000; Setboonsarng, 2006). Hence, this section aims at summarising some underexplored empirical insights on how to better tackle poverty through transport development.

\subsection{Intersectionality and travel behaviour}

Over the past few years, authors have ever more seen the relationship between transport and poverty through the lens of an intersectional view of exclusion (Kabia et al, 2018; Oviedo et al, 2017; Levy, 2013). The concept of intersectionality was originally coined by Crenshaw (1989) when proposing that the intersectional exclusion experienced by black women is even greater than the sum of racism or sexism experienced separately. After its inception, other interlocking and mutually reinforcing vectors of exclusion have been also considered to expand this concept to class, ethnicity, disabilities, age, religion, etc (Nash, 2008). Two out of all these vectors appear to have received particularly more attention in recent studies addressing the impact of intersectionality on travel behaviour.

Firstly, gender has been widely considered as a crucial factor that affects how low-income people benefit from the development of transport services and infrastructure. Authors have argued that transport policies must be gender-sensitive to be effective in tackling poverty since women face different challenges than men in accessing, using and paying for transport services (Babinard et al, 
2010; Salon and Gulyani, 2010; Anand and Tiwar, 2006). Cook et al (2005) illustrate this pointing that depending on the quality, reliability and security of the transport services, parents from India, Thailand, and China are more prone to allow girls to carry on with their education and to participate in social and economic activities outside the villages, which is an essential step to enabling low-income girls in improving their future livelihood and well-being. A more extreme example reported by Babinard et al (2010) underlines that, if not well planned, the opening of new transport corridors in localities where poverty is most spread may implicate in trafficking of girls and women, especially in remote localities. Kabia et al (2018) report that the intersections of gender, poverty, and disability in Kenya have resulted not only in limited mobility for them but also in less awareness about health services since they are usually excluded from public participation forums due to negative stereotypes attributed to them.

The second major aspect found was that transport policies targeting these people should first consider the impact of income poverty on travel patterns (Vasconcellos, 2018; Sadhu and Tiwari, 2016; Motte-Baumvol and Nassi, 2012; Lau, 2010). Some authors have demonstrated empirically that in many regions the concept of travel choice cannot be applied to people living in extreme income poverty, because mostly there is no choice, but walking (Sadhu and Tiwari, 2016; Salon and Gulyani, 2010; and Cook et al, 2005). In fact, low-income people may continue to use non-motorised transports even in a brand-new road since they do not have automobiles nor enough resources to afford a new one (Porter, 2002; Setboonsarng, 2006; and Raballand et al, 2011). Similarly, authors have also stressed how vital informal transport is for helping vulnerable people to overcome social exclusion since it is usually the only type of public transport flexible enough to overcome geographical, economic and social barriers (Evans et al, 2018; Hernandez and Titheridge, 2016). In that sense, it is argued that large investments in transport infrastructure construction that disregard informal and non-motorised transports are not enough to guarantee poverty alleviation.

These examples attempt to illustrate the travel pattern outcomes of intersecting social features and transport-related exclusions. These insights shed light to the importance of not only evaluate the outputs of transport development (such as road length, or quantity of buses delivered), but also the outcomes of it, such as accessibility improvement and social development.

\subsection{Prioritisation by accessibility analysis}

A nearly ubiquitous policy recommendation of the reviewed studies is that accessibility analysis (including the spatial, social and economic distributional effects) should be an essential driver of transport appraisals utilised in the prioritisation process of transport investments. This would be conducted with traditional travel demand, cost-benefit and wider economic benefit analysis, this type of assessment is paramount to identify the differences in access to life-enhancing opportunities (education, health care, employment, etc) among different locations (rural/urban, centre/peripheral 
areas), socio-economic features (e.g. income groups, age, gender, ethnicity, etc), and modes resulting a more transparent and equitable transport planning.

Vasconcellos (2011) argues that equity audits are needed to refrain the 'more common, limited pseudo-scientific technical approach to urban transport appraisal'. Reinforcing previous studies (Bryceson et al, 2003; Lau, 2010) Guzman et al (2017) also sustain that the redistribution of current levels of accessibility should be guided by assessments of access to employment and education between income groups.

Particular attention to the most vulnerable income groups has been also consistently suggested as a high priority for achieving a fair transport system (Vermeiren et al, 2015; Li and Da Costa, 2013). Drawing on expert opinion surveys and empirical evidence from Ghana and Uganda, Naimanye and Whiteing (2016) hold that the allocation of funds for rural roads should be poverty-centred to provide equality of transport opportunities. In a systematic reflection on the key theories of justice (utilitarianism, libertarianism, intuitionism, Rawl's egalitarianism, and capability approach) Pereira et al (2017) propose a framework for evaluating transport policies by detailed analysis of their distributional effects. According to the authors, such a framework should consider accessibility to key destinations, preservation of individuals' rights, prioritisation of disadvantaged groups, reduction of inequalities of opportunities, and finally, mitigation of transport externalities.

\subsection{Private agendas of policymakers}

When considering transport projects led by the public sector, some political dimensions, that are often overlooked in academic studies, also need to be explored to shed light on the reasons why transport policies have not been more effective in tackling poverty. As highlighted by Benitez et al (2010) there are at least four power- and money-seeking private agendas in the realm of infrastructure policymakers which affect negatively transport development:

- Populism/re-election: Excessively strong focus on fitting infrastructure projects in the electoral calendar (short-term), instead of following an appropriate long-term development agenda. Remarkable preference for what is visible rather than necessary investments;

- Patronage: Support and bolster power for an elite control over a sector. It is a mechanism of long-term power-hunt that focus on prioritisation of certain people to control strategic departments (e.g. regulatory institutions, state agencies) to facilitate for party allies controlling the country; overall

- Industry-friendliness: Agreements made among politicians and private sector representatives in order to achieve revenues for the party or new business for party allies in exchange of assuring future concession contracts or more profitable projects for specific private companies; 
- Corruption: Increase personal incomes by illegal appropriation of fractions of projects' budgets usually in exchange for manipulating the bidding process to assure that specifics contractors will be hired.

It is argued that the infrastructure development is often hampered and misdirected by these private agendas of decision-makers, especially in countries from Global South where there are weak accountability and low-performance evaluation of this sector (Benitez et al, 2010). The likely consequences of these setbacks in the political arena can be illustrated in the following situations:

1. Prioritisation of transport projects based on bribes, rather than appropriate planning ${ }^{1}$;

2. Subsidies to enhance accessibility and affordability frequently get lost in corruption ${ }^{3}$;

3. Limited access to information (data) of transport sector performance to ensure less accountability ${ }^{3}$;

4. Weaken of regulatory agencies and technical departments ${ }^{3}$;

5. Great expenses with many pre-feasibility studies with no continuity because of low credibility of political decisions ${ }^{3}$;

6. Allocation of resources driven by industry-friendliness and patronage, rather than by social return ${ }^{2}$

7. High appetite for transport infrastructure investments particularly during periods leading to elections, rather than following a consistent long-term investment plan;

8. Transport investments focused on what is visible rather than what is needed ${ }^{3}$;

9. Favourability of specific suppliers, reducing market competition and worsening the transport service quality ${ }^{3}$;

10.Frequent unclear renegotiation of concession contracts resulting in money evasion to corruption schemes ${ }^{3}$;

11.Selection of projects focusing on flagship construction (media-attractors), rather than maintenance of remote rural roads ${ }^{4}$;

12. Expansion of transport contracts without concern on affordability for the poorest ${ }^{5}$.

\subsection{Transport and intergenerational poverty transfer}

Sachs (2008), suggested that poverty will not be ended by sheer will power nor by ethical commitment alone. Rather, it will be ended only by bringing the best of our thinking and science together with the ethical commitment of scholars and practitioners from across the range of human knowledge (Sachs, 2008). Therefore, this following section by no means aims to offer a panacea for

\footnotetext{
${ }^{1}$ See Benitez et al (2010) for more on this

2 See Asomani-Boateng et al (2015) for more on this

${ }^{3}$ See Guasch (2004) for more on this

4 See Setboonsarng (2006) for more on this

${ }^{5}$ See Fuenmayor et al (2017) for more on this
} 
such a complex problem. Conversely, what is proposed is how transport planners and practitioners could more effectively contribute to this multi-dimensional solution.

Vakis et al (2016) define as 'chronic poor' people who are born into poverty and may never escape from it. Based on surveys and Censuses' analysis in Latin America and the Caribbean, these authors have concluded that the main difference between the chronic poor and those who escaped poverty is essentially the access to services, subscribing to the view that accessibility is not only inextricably linked with, but it can also reinforce cycles of poverty. Porter et al (2007) observe that poor health and education, as well as poor job opportunities, are likely to be transferred to the next generation if the same circumstances of lack of social networks and poor access to health and education services are maintained. Fang and Zou (2014) also emphasises that improvements in transport infrastructure can increase the living standards of young generations and break the intergenerational poverty transfer.

In that sense, drawing upon the eight transport-related exclusion categories (described in section 3.1) and the relationship of transport disadvantage and social exclusion proposed by Lucas (2012), Figure 1 attempts to summarise the key strategies of transport development and their potential accessibility outcomes that could tackle the structures, processes, and livelihood strategies that can affect intergenerational poverty transfer according to Hulme et al (2001).

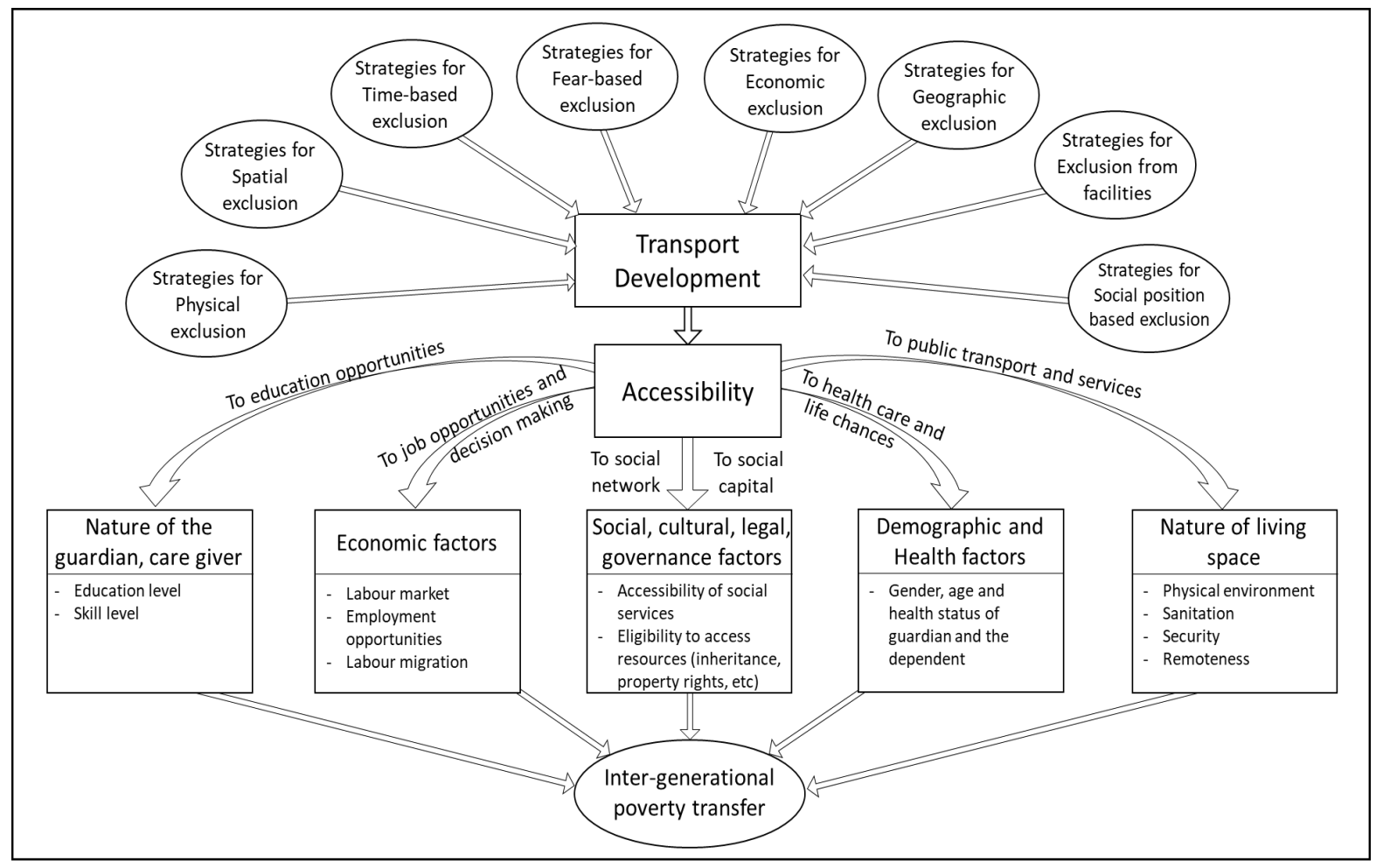

Figure 3: Diagram to illustrate the potential contributions of transport development to the structures, processes, and livelihood strategies that can affect inter-generational poverty transfer 


\section{Gaps in the literature and research agenda}

Although there is an increasing stock of knowledge underpinning links between Transport and Poverty in the Global South, several omissions and limitations have been persistently reported. Many authors attribute the gaps of research inter-relating transport improvements and poverty alleviation to the lack of reliable data (Sanchez, 2008; Salon and Gulyani, 2010; Porter, 2014). In fact, the Millennium Development Goals (MDG) Report (2015) considers the following dimensions as the major challenges in terms of data collection: (1) Poor data quality; (2) lack of timely data and; (3) unavailability of disaggregated data. The same report also points out that almost half of 155 assessed countries lack adequate data to monitor poverty.

In terms of transport-related data, even larger limitations have been consistently reported on the availability and accuracy of maps of the transport network (i.e. roads, footpaths, cycle lanes, railways, etc), General Transit Feed Specification (GTFS) data (including routes, timetables and location of stops of public transport), travel surveys, level of infrastructure quality/maintenance, location of opportunities and services (i.e. schools, health care, jobs, parks, etc) (Pritchard et al, 2019; Pereira, 2019; Oloo, 2018; Evans et al, 2018).

As a result, such lack of accurate, timely and disaggregated poverty and transport-related data warps the perception about the transport metabolism (Vasconcellos, 2005) and mislead planners and decision makers to a less socially-driven transport development. Dimitriou (2013) suggests that this scenario of data deprivation entails a trade-off between model sophistication and data availability, which usually implicate in the creation of simplistic and sometimes unrealistic transport planning models.

In terms ex-post studies, the reviewed papers' methodologies tend to converge around quasiexperimental methods (also called nonexperimental evaluation or observational study) when assessing the impacts of transport investments (e.g. construction of rural roads, BRT's, metrocables, pro-poor subsidies on fares, etc) on poverty reduction (Qin and Zhang, 2016; Rodriguez et al, 2016; Bocarejo et al, 2014; Khandker, 2009). However, Ravallion (2007) asserts that this methodology is quite data demanding and, therefore, limitations in the spatial and timely disaggregation of such data might give rise to endogeneity (i.e. invalidation of causal claims due to non-observed variables) and heterogeneity (i.e. differences between groups not due to chance) issues when assessing the treatment effect of transport investments on poverty reduction.

In complement to the current level of evidence addressing transport-related exclusions, authors have emphasised that further investigations are needed disaggregating analysis by:

- Services: Education (primary/secondary) and Healthcare (emergency/basic care) should be also disaggregated by public/private provider (Fuenmayor, et al (2017); 
- Socio-economic features: including income groups (Guzman et al, 2017b), gender (Anand and Tiwari, 2006) and age-specific analysis (Porter, 2013);

- Transport modes: including informal (Evans et al, 2018) and non-motorised modes (MotteBaumvol and Nassi, 2012);

- Location: rural/urban (Fan and Chan-Kang, 2008) and central/peripheral areas (Rodriguez et al, 2016);

- Job opportunities: separating by job requirements (Pereira, 2019) and including informal jobs (Pritchard, 2019).

\section{Policy Implications}

In the academic dialogue on transport policy much has been written on implications and approaches in the developed world, whereas the developing world has garnered comparably much less attention, as discussed in Lucas et al (2016). This paper builds upon the seminal transport policy analysis framework published by Church et al (2000) and adapts it into the Global South context. The paper describes how issues in transport policy analysis in the Global South are different from the rest of the world and how new analysis tools are required.

The adaptation of the Church et al (2000) framework comes in the format of an eighth stage to the seven-stage framework that examines transport-related exclusion. This additional stage is demonstrated, with reference to the literature, to be appropriate for the Global South and its addition adapts a framework developed for London to this region. One of the main contributions of this work is to demonstrate that the issues in the Global South for transport policy appraisal may not be fully addressed using tools from developed countries. The approach documented provides policymakers and practitioners with an alternative framework to address transport policies in cities and regions in the Global South.

\section{Conclusions}

Overall, this literature overview suggests that the scarcity of poverty and transport-related data about the most disadvantaged regions (UN, 2015) limits the development of solid and effective research about transport-related exclusion in the Global South (Porter, 2002; Salon and Gulyani, 2010). Under this low research production context, and many misperceptions about the impacts of intersectionality on travel patterns (Levy, 2013), transport policy recommendations that should be guided by disaggregated accessibility and equity analysis (Vasconcellos, 2011) are frequently inaccurate and socially unjust (Pereira et al, 2017). In a political context of low transparency and low accountability that also lacks such evidence-based policy recommendations, policy-makers are likely to mislead transport investments towards their own private agendas (Benitez, 2010). As a result, a debilitating and unconstrained transport and urban development are perpetuated reinforcing cycles of chronic poverty (UN, 2016; Hulme et al, 2001). 
By pointing out and connecting such underexplored insights on the transport-poverty nexus in the Global South, this study has argued that new transport policies should comprehend strategies to addressing the eight mentioned transport-related dimensions of exclusion, if the goal is to end poverty in all its manifestations by 2030 . The gravity and urgency of lifting 1.3 billion people out of poverty are translated by Narayan et al's (2000) definition of poverty:

"Poverty is pain. Poor people suffer physical pain that comes with too little food and long hours of work; emotional pain stemming from the daily humiliations of dependency and lack of power; and the moral pain from being forced to make choices such as whether to pay to save the life of an ill family member or to use the money to feed their children. "

Undeniably, while many political leaders insist to claim that we are finally the generation that can end extreme poverty, this will not come true until professionals from across the range of human knowledge start working strongly committed towards this direction. This paper has raised evidence that can be a valuable input to call particular attention to the essential role that transport academics and practitioners ought to play in order to stand up to poverty when developing new transport policies.

\section{REFERENCES}

Adeel, M., Yeh, A.G.O. and Zhang, F., 2016. Transportation disadvantage and activity participation in the cities of Rawalpindi and Islamabad, Pakistan. Transport Policy, 47, pp.1-12. DOI:10.1016/j.tranpol.2015.12.001

Agbenyo, F., Nunbogu, A.M. and Dongzagla, A., 2017. Accessibility mapping of health facilities in rural Ghana. Journal of Transport \& Health, 6, pp.73-83. DOI:10.1016/j.jth.2017.04.010

Alkire, S. and Foster, J., 2011. Counting and multidimensional poverty measurement, Journal of Public Economics 95, 476-487. DOI:10.1016/j.jpubeco.2010.11.006

Alkire, S. and Santos M. E., 2014. Measuring Accurate Poverty in the Developing World: Robustness and Scope of the Multidimensional Poverty Index. World Development Vol. 59, 251-274. DOI:10.1016/j.worlddev.2014.01.026

Alkire, S., Chatterjee, M., Conconi, A., Seth, S., Vaz, A., 2014. Poverty in Rural and Urban Areas: Direct comparisons using the global MPI, The Oxford Poverty and Human Development Initiative (OPHI), Briefing 24

Anand, A. and Tiwari, G., 2006. A gendered perspective of the shelter-transport-livelihood link: the case of poor women in Delhi. Transport Reviews, 26(1), pp.63-80. DOI:10.1080/01441640500175615

Armstrong-Wrigh, A., 1986. Urban Transit Systems, World Bank Technical paper number 52.

Asomani-Boateng, R., Fricano, R.J. and Adarkwa, F., 2015. Assessing the socio-economic impacts of rural road improvements in Ghana: a case study of Transport Sector Program Support (II). Case studies on transport policy, 3(4), pp.355-366. DOI:10.1016/j.cstp.2015.04.006

Babinard, J.; Hine, J.; Ellis, S.; Ishihara, S.. 2010. Mainstreaming gender in road transport : operational guidance for World Bank staff. Transport paper series ; no. TP-28. Washington, DC: World Bank.

Benitez, D., Estache, A. and Søreide, T., 2010. Dealing with politics for money and power in infrastructure. The World Bank. DOI:10.1596/1813-9450-5455

Beuran, M., Gachassin, M. and Raballand, G., 2015. Are There Myths on Road Impact and Transport in SubSaharan Africa?. Development Policy Review, 33(5), pp.673-700. DOI:10.1111/dpr.12125

Blanco, J., Lucas, K., Schafran, A., Apaolaza, R. (2018). Contested mobilities in the Latin American context. Journal of Transport Geography, 67, 73-75. DOI:10.1016/j.jtrangeo.2018.01.006 
Bocarejo, J.P., Portilla, I.J., Velásquez, J.M., Cruz, M.N., Peña, A. and Oviedo, D.R., 2014. An innovative transit system and its impact on low income users: the case of the Metrocable in Medellín. Journal of Transport Geography, 39, pp.49-61. DOI:10.1016/j.jtrangeo.2014.06.018

Booth, D., L. Hanmer, and E. Lovell. 2000. Poverty and transport: a report prepared for the World Bank in collaboration with DFID Overseas Development Institute: London.

Bryceson, D.F., Mbara, T.C. and Maunder, D., 2003. Livelihoods, daily mobility and poverty in sub-Saharan Africa. Transport reviews, 23(2), pp.177-196. DOI:10.1080/01441640309891

Cano, I., 2010. Racial bias in police use of lethal force in Brazil. Police Practice and Research: An International Journal, 11(1), pp.31-43.

Cass, N., Shove, E. and Urry, J., 2005. Social exclusion, mobility and access 1. The sociological review, 53(3), pp.539-555. DOI:10.1111/j.1467-954X.2005.00565.x

Church, A., Frost, M. and Sullivan, K., 2000. Transport and social exclusion in London. Transport Policy, 7(3), pp.195-205. DOI:10.1016/S0967-070X(00)00024-X

Cook, Cynthia C.; Duncan, Tyrell; Jitsuchon, Somchai; Sharma, Anil; Guobao, Wu. 2005. Assessing the Impact of Transport and Energy Infrastructure on Poverty Reduction. (c) Asian Development Bank. $<$ http://hdl.handle.net/11540/240>.

Crenshaw, K., 1989. Demarginalizing the intersection of race and sex: A black feminist critique of antidiscrimination doctrine, feminist theory and antiracist politics. U. Chi. Legal F., p.139.

Currie, G. and Delbosc, A., 2010. Modelling the social and psychological impacts of transport disadvantage. Transportation, 37(6), pp.953-966. DOI:10.1007/s11116-010-9280-2

De Luca, G.D., 2007. Roads, Development and Deforestation: a review. Development Research Group Paper. The World Bank.

Deng, H., Li, Y., Li, W. and Yu, Y., 2016. Urban transport social needs in China: Quantification with central government transit grant. Transport Policy, 51, pp.126-139. DOI:10.1016/j.tranpol.2016.07.005

Dillon, A., Sharma, M. and Zhang, X., 2011. Estimating the impact of rural investments in Nepal. Food Policy, 36(2), pp.250-258. DOI:10.1016/j.foodpol.2010.11.022

Dimitriou, H.T. ed., 2013. Transport Planning for Third World Cities (Routledge Revivals). Routledge. pp 280-292.

Evans, J., O'Brien, J. and Ch Ng, B., 2018. Towards a geography of informal transport: Mobility, infrastructure and urban sustainability from the back of a motorbike. Transactions of the Institute of British Geographers. DOI:10.1111/tran.12239

Fan, S. and Chan-Kang, C., 2008. Regional road development, rural and urban poverty: Evidence from China. Transport Policy, 15(5), pp.305-314. DOI:10.1016/j.tranpol.2008.12.012

Fang, Y. and Zou, W., 2014. Neighborhood effects and regional poverty traps in rural China. China \& world economy, 22(1), pp.83-102. DOI:10.1111/j.1749-124X.2014.12054.X

Farrow, A., Larrea, C., Hyman, G. and Lema, G., 2005. Exploring the spatial variation of food poverty in Ecuador. Food policy, 30(5), pp.510-531. DOI:10.1016/j.foodpol.2005.09.005

Fuenmayor, G.J., Hunt, J.D. and Abraham, J.E., 2017. Impact of Transit Fare Increase in Caracas, Venezuela: Analysis Using PECAS Model (No. 17-01764).

Gannon, C.A. and Liu, Z., 1997. Poverty and transport (No. TWU-30). Washington, DC: World Bank.

Guasch, J.L., 2004. Granting and renegotiating infrastructure concessions: doing it right. World Bank Publications.

Guzman, L.A., Oviedo, D. and Rivera, C., 2017a. Assessing equity in transport accessibility to work and study: The Bogotá region. Journal of Transport Geography, 58, pp.236-246. DOI:10.1016/j.jtrangeo.2016.12.016

Guzman, L.A., Oviedo, D., Rivera, C., Rodriguez, C. and Peralta-Quiros, T., 2017b. Accessibility and Poverty: Assessing Public Transport Subsidies in Bogotá. TRB Conference No. 17-01180.

Hanmer, L., Booth, D. and Lovell, E., 2000. Poverty and Transport. A Report prepared for the World Bank in collaboration with DFID, Overseas Development Institute. DOI:10.2139/ssrn. 1754546

Hansen, W.G., 1959. How accessibility shapes land use. Journal of the American Institute of planners, 25(2), pp.73-76. DOI:10.1080/01944365908978307

Hanson, S., Hanson, P., 1980. Gender and urban activity patterns in Uppsala, Sweden. Geogr. Rev. 70, 291299. DOI: $10.2307 / 214257$ 
Harvey, D., 1980. A justiça social ea cidade. Hucitec. p. 116

Hernandez, D., 2018. Uneven mobilities, uneven opportunities: Social distribution of public transport accessibility to jobs and education in Montevideo. Journal of Transport Geography, 67, pp.119-125. DOI:10.1016/j.jtrangeo.2017.08.017

Hernandez, D.O. and Titheridge, H., 2016. Mobilities of the periphery: informality, access and social exclusion in the urban fringe in Colombia. Journal of transport geography, 55, pp.152-164. DOI:10.1016/j.jtrangeo.2015.12.004

Hine, J. and Mitchell, F., 2017. Transport disadvantage and social exclusion: exclusionary mechanisms in transport in urban Scotland. Routledge. DOI:10.4324/9781315235677

Hulme, D., Moore, K. and Shepherd, A., 2001. Chronic poverty: meanings and analytical frameworks. Chronic Poverty Research Centre Working Paper, (2).

International Fund for Agricultural Development, 2011. Rural poverty report (2011), IFAD, Rome.

Kabia, E., Mbau, R., Muraya, K.W., Morgan, R., Molyneux, S. and Barasa, E., 2018. How do gender and disability influence the ability of the poor to benefit from pro-poor health financing policies in Kenya? An intersectional analysis. International journal for equity in health, 17(1), p.149. DOI:10.1186/s12939-0180853-6

Kenyon, S., Lyons, G. and Rafferty, J., 2002. Transport and social exclusion: investigating the possibility of promoting inclusion through virtual mobility. Journal of Transport Geography, 10(3), pp.207-219. DOI:10.1016/S0966-6923(02)00012-1

Khan, S., Combaz, E. \& McAslan Fraser, E. (2015). Social exclusion: topic guide. Revised edition. Birmingham, UK: GSDRC, University of Birmingham.

Khandker, S.R., Bakht, Z. and Koolwal, G.B., 2009. The poverty impact of rural roads: evidence from Bangladesh. Economic Development and Cultural Change, 57(4),pp.685-722. DOI:10.1086/598765

Lau, J.C.Y., 2010. The influence of suburbanization on the access to employment of workers in the new towns: A case study of Tin Shui Wai, Hong Kong. Habitat international, 34(1), pp.38-45. DOI:10.1016/j.habitatint.2009.05.002

Lau, J.C.Y., 2013. Sustainable urban transport planning and the commuting patterns of poor workers in a historic inner city in Guangzhou, China. Habitat International, 39, pp.119-127. DOI: 10.1016/j.habitatint.2012.11.006

Lefebvre, H., 1974. La production de l'espace. L'Homme et la société, 31(1), pp.15-32.

Levy, C. and Dávila, J.D., 2017. Planning for Mobility and Socio-Environmental Justice: The Case of Medellín, Colombia. In Environmental Justice and Urban Resilience in the Global South (pp. 37-55). Palgrave Macmillan, New York.

Levy, C., 2013. Travel choice reframed: "deep distribution" and gender in urban transport. Environment and Urbanization, 25(1), pp.47-63. DOI:10.1177/0956247813477810

Li, Y. and DaCosta, M.N., 2013. Transportation and income inequality in China: 1978-2007. Transportation Research Part A: Policy and Practice, 55, pp.56-71. DOI:10.1016/j.tra.2013.08.006

Lionjanga, N. and Venter, C., 2018. Does public transport accessibility enhance subjective well-being? A study of the City of Johannesburg. Research in Transportation Economics, 69, pp.523-535. DOI:10.1016/j.retrec.2018.07.011

Lofgren, H., Robinson, S. and Thurlow, J., 2004. Prospects for growth and poverty reduction in Zambia, 20012015.

Lucas, K., 2011. Making the connections between transport disadvantage and the social exclusion of low income populations in the Tshwane Region of South Africa. Journal of Transport Geography, 19, 1320-1334. DOI:10.1016/j.jtrangeo.2011.02.007

Lucas, K., 2012. Transport and social exclusion: Where are we now? Transport Policy, 20,105-113. DOI:10.1016/j.tranpol.2012.01.013

Lucas, K., Mattioli, G., Verlinghieri, E. and Guzman, A., 2016. Transport poverty and its adverse social consequences. In Proceedings of the institution of civil engineers-transport (Vol. 169, No. 6, pp. 353-365). Thomas Telford (ICE Publishing). DOI:10.1680/jtran.15.00073

Motte-Baumvol, B. and Nassi, C.D., 2012. Immobility in Rio de Janeiro, beyond poverty. Journal of Transport geography, 24, pp.67-76. DOI:10.1016/j.jtrangeo.2012.06.012 
Naimanye, A.G. and Whiteing, T., 2016, October. Poverty-centred rural road funds sharing in sub-Saharan Africa. In Proceedings of the Institution of Civil Engineers-Transport (Vol. 169, No. 6, pp. 387-396). Thomas Telford Ltd. DOI:10.1680/jtran.15.00071

Narayan, D., Patel, R., Schafft, K., Rademacher, A., Koch-Schulte, S., 2000. Voices of the poor Can anyone hear us? Oxford University Press for the World Bank.

Nash, J.C., 2008. Re-thinking intersectionality. Feminist review, 89(1), pp.1-15. DOI:10.1057/fr.2008.4

Nigriello, A., 1992. O Impacto do Sistema de Transporte sobre o Espaço Urbano e seu Controle. Pós. Revista do Programa de Pós-Graduação em Arquitetura e Urbanismo da FAUUSP, 1(2), pp.47-54.

Oloo, F., 2018. Mapping Rural Road Networks from Global Positioning System (GPS) Trajectories of Motorcycle Taxis in Sigomre Area, Siaya County, Kenya. ISPRS International Journal of Geo-Information, 7(8), p.309. DOI:10.3390/ijgi7080309

Ormerod, M., Newton, R., Phillips, J., Musselwhite, C., McGee, S. and Russell, R., 2015. How can transport provision and associated built environment infrastructure be enhanced and developed to support the mobility needs of individuals as they age. Future of an ageing population: evidence review Foresight, Government Office for Science, London, UK.

Ornati, O.A., Whittaker, J.W. and Solomon, R., 1969. Transportation needs of the poor: A case study of New York City. Praeger.

Oviedo, D., Levy, C. and D'avila, J, 2017. Constructing wellbeing, deconstructing urban (im)mobilities in Abuja, Nigeria. In Urban Mobilities in the Global South (pp. 193-214). Routledge)

Özkazanç, S. and Sönmez, F.N.Ö., 2017. Spatial analysis of social exclusion from a transportation perspective: A case study of Ankara metropolitan area. Cities, 67, pp.74-84. DOI:10.1016/j.cities.2017.04.013

Pawson, R., Greenhalgh, T., Harvey, G. and Walshe, K., 2005. Realist review-a new method of systematic review designed for complex policy interventions. Journal of health services research \& policy, 10(1_suppl), pp.21-34. DOI:10.1258/1355819054308530

Pereira, R.H., 2019. Future accessibility impacts of transport policy scenarios: equity and sensitivity to travel time thresholds for Bus Rapid Transit expansion in Rio de Janeiro. Journal of Transport Geography, 74, pp.321-332. DOI:10.1016/j.jtrangeo.2018.12.005

Pereira, R.H., Schwanen, T. and Banister, D., 2017. Distributive justice and equity in transportation. Transport Reviews, 37(2), pp.170-191. DOI: 10.1080/01441647.2016.1257660

Porter, G., 2002. Living in a walking world: rural mobility and social equity issues in sub-Saharan Africa. World development, 30(2), 285-300. DOI:10.1016/S0305-750X(01)00106-1

Porter, G., 2014. Transport services and their impact on poverty and growth in rural sub-Saharan Africa: A review of recent research and future research needs. Transport reviews, 34(1), 25-45. DOI:10.1080/01441647.2013. 865148

Porter, G., Blaufuss, K. and Acheampong, F.O., 2007. Youth, mobility and rural livelihoods in sub-Saharan Africa: Perspectives from Ghana and Nigeria: Poverty, development and livelihoods. Africa insight, 37(3), pp.420431. DOI:10.4314/ai.v37i3.22500

Porter, G., Hampshire, K., Abane, A., Munthali, A., Robson, E., Mashiri, M. and Tanle, A., 2012. Youth, mobility and mobile phones in Africa: findings from a three-country study. Information Technology for Development, 18(2), pp.145-162 DOI:10.1080/02681102.2011.643210

Porter, G., Tewodros, A., Bifandimu, F., Gorman, M., Heslop, A., Sibale, E., Awadh, A. and Kiswaga, L., 2013. Transport and mobility constraints in an aging population: health and livelihood implications in rural Tanzania. Journal of Transport Geography, 30, pp.161-169. DOI:10.1016/j.jtrangeo.2013.05.001

Pritchard, J.P., Tomasiello, D.B., Giannotti, M. and Geurs, K., 2019. Potential impacts of bike-and-ride on job accessibility and spatial equity in São Paulo, Brazil. Transportation Research Part A: Policy and Practice, 121, pp.386-400. DOI:10.1016/j.tra.2019.01.022

Qin, Y. and Zhang, X., 2016. The road to specialization in agricultural production: Evidence from rural China. World Development, 77, pp.1-16. DOI:10.1016/j.worlddev.2015.08.007

Raballand, G., Thornton, R.L., Yang, D., Goldberg, J., Keleher, N.C. and Müller, A., 2011. Are rural road investments alone sufficient to generate transport flows? Lessons from a randomized experiment in rural Malawi and policy implications.

Rajkhan, S., 2014. Women in Saudi Arabia: Status, rights, and limitations. A paper submitted to the faculty of the University of Washington Bothell in candidacy for the degree of Master of Arts in Policy Studies. 
Ramos, S., \& Musumeci, L. (2005). Elemento suspeito: Abordagem policial e discriminação na cidade do Rio de Janeiro. Rio de Janeiro: Civilização Brasileira.

Ravallion, M., 2007. Evaluating anti-poverty programs. Handbook of development economics, 4, pp.3787-3846. DOI:10.1016/S1573-4471(07)04059-4

Rodríguez, C., Gallego, J.M., Martinez, D., Montoya, S. and Peralta-Quiros, T., 2016. Examining Implementation and Labor Market Outcomes of Targeted Transit Subsidies: Subsidy by Sistema Nacional de Selección de Beneficiarios for Urban Poor in Bogotá, Colombia. Transportation Research Record: Journal of the Transportation Research Board, (2581), pp.9-17. DOI:10.3141/2581-02

Rynning, M. K., Uteng, T.P. and Lucas, K., 2017. Epilogue: Creating planning knowledge through dialogues between research and practice. Urban mobilities in the global south. Routledge.

Sachs, J., 2008. The end of poverty: economic possibilities for our time. European Journal of Dental Education, 12, pp.17-21. DOI:10.1111/j.1600-0579.2007.00476.x

Sadhu, S.S. and Tiwari, G., 2016. An activity pattern-destination land use choice model of low income households of informal settlements-Case study of Delhi. Transportation Research Part A: Policy and Practice, 85, pp.265-275. DOI:10.1016/j.tra.2016.01.017

Salon, D. and Gulyani, S., 2010. Mobility, poverty, and gender: travel 'choices' of slum residents in Nairobi, Kenya. Transport Reviews, 30(5), 641-657. DOI:10.1080/01441640903298998

Sanchez, T.W., 2008. Poverty, policy, and public transportation. Transportation Research Part A: Policy and Practice, 42(5), 833-841. DOI:10.1016/j.tra.2008.01.011

Seekings, J., 2008. The continuing salience of race: Discrimination and diversity in South Africa. Journal of contemporary African studies, 26(1), pp.1-25.

Seiler, C., 2007. The significance of race to transport history. The Journal of Transport History, 28(2), pp.307311.

Setboonsarng, S. 2006. Transport Infrastructure and Poverty Reduction. (c) Asian Development Bank. <http://hdl.handle.net/11540/4064>.

Social Exclusion Unit, 2003. Making the Connections: Final report on Transport and Social Exclusion. Office of the Deputy Prime Minister, London.

Stifel, D. and Minten, B., 2017. Market access, well-being, and nutrition: evidence from Ethiopia. World Development, 90, pp.229-241. DOI:10.1016/j.worlddev.2016.09.009

Stifel, D., Minten, B. and Koru, B., 2016. Economic Benefits of Rural Feeder Roads: Evidence from Ethiopia. The Journal of Development Studies, 52(9), pp.1335-1356. DOI:10.1080/00220388.2016.1175555

Titheridge, H., Mackett, R.L., Christie, N., Oviedo Hernández, D. and Ye, R., 2014. Transport and poverty: a review of the evidence.

UN Environment, 2016. Global Outlook on Walking and Cycling. UN Environment, Nairobi.

UN, 1995. The Copenhagen declaration and programme of action: World summit for social development 6-12 March 1995, New York: United Nations Department of Publications

UN, 2015. The Millennium Development Goals Report.

UN, 2019. Sustainable Development Goals. Goal 1: No poverty. Facts and figures. Retrieved at 15/02/2019 from https://www.undp.org/content/undp/en/home/sustainable-development-goals/goal-1-no-poverty.html

Vajjhala, S.P. and Walker, W.M., 2010. Roads to participatory planning: Integrating cognitive Mapping and GIS for transport prioritization in rural Lesotho. Journal of Maps, 6(1), pp.488-504. DOI:10.4113/jom.2010.1086

Vakis, R., Rigolini, J., Lucchetti, L., 2016. Left Behind: Chronic Poverty in Latin America and the Caribbean. World Bank. (C https://openknowledge.worldbank.org/handle/10986/21552

Vasconcellos, E., 2001. Urban Transport: Environment and Equity: The Case for Developing Countries, Earthscan, London and Sterling VA, 333 pages.

Vasconcellos, E.A., 2005. Urban change, mobility and transport in São Paulo: three decades, three cities. Transport Policy, 12(2), pp.91-104. DOI:10.1016/j.tranpol.2004.12.001

Vasconcellos, E.A., 2011. 12 Equity evaluation of urban transport. Urban transport in the developing world: a handbook of policy and practice, p.332.

Vasconcellos, E.A., 2018. Urban transport policies in Brazil: The creation of a discriminatory mobility system. Journal of transport geography, 67. DOI:10.1016/j.jtrangeo.2017.08.014 
Venter, C., 2011. Transport expenditure and affordability: The cost of being mobile. Development Southern Africa, 28(1), pp.121-140. DOI:10.1080/0376835X.2011.545174

Vermeiren, K., Verachtert, E., Kasaija, P., Loopmans, M., Poesen, J. and Van Rompaey, A., 2015. Who could benefit from a bus rapid transit system in cities from developing countries? A case study from Kampala, Uganda. Journal of Transport Geography, 47, pp.13-22. DOI:10.1016/j.jtrangeo.2015.07.006

Wachs, M. and Kumagai, T.G., 1973. Physical accessibility as a social indicator. Socio-Economic Planning Sciences, 7(5), 437-456. DOI:10.1016/0038-0121(73)90041-4

Warr, P., 2005. Road development and poverty reduction: The case of Lao PDR (No. 64). ADBI Research Paper Series.

Wee, B.V. and Banister, D., 2016. How to write a literature review paper?. Transport Reviews, 36(2), pp.278-288. DOI:10.1080/01441647.2015.1065456

Wixey, S., Jones, P., Lucas, K. and Aldridge, M., 2005. Measuring accessibility as experienced by different socially disadvantaged groups. London, Transit Studies Group, University of Westminster.

World Bank. 2017. Monitoring Global Poverty: Report of the Commission on Global Poverty. Washington, DC: World Bank. <https://openknowledge.worldbank.org/handle/10986/25141>.

Zou, W., Zhang, F., Zhuang, Z. and Song, H., 2008. Transport Infrastructure, Growth, and Poverty Alleviation: Empirical Analysis of China. Annals of Economics \& Finance, 9(2). 